\title{
ANALISIS KETIMPANGAN PENDAPATAN DAN IDENTIFIKASI SEKTOR BASIS ANTAR KECAMATAN DI KABUPATEN WONOGIRI TAHUN 2010-2014
}

\author{
Alit Pamrihnan', Malik Cahyadin² \\ ${ }^{1,2}$ Fakultas Ekonomi dan Bisnis, Universitas Sebelas Maret \\ Email: alitpamrihnan@gmail.com, malikcahyadin@gmail.com
}

\begin{abstract}
This study aims to determine the level of inequality and base economic of Wonogiri Districts in 2010-2014. This study uses secondary data involve Gross Regional Domestic Product (GRDP) at Constant Price of 2000, GRDP per capita, Population and Economic Growth. The analytical method uses analysis of Williamson Index, Theil Entropy Index, Static Location Quotient (SLQ) and Dynamic Location Quotient (DLQ).

Research results show that the Williamson Index of Wonogiri District tends to decrease, the higest level of income inequality happened in the Wonogiri Subdistric and the lowest level of income inequality happened in the Eromoko Subdistric. Entropy Theil index shows that inequality between subdistrict in Wonogiri District tends to decrease. Karangtengah Subdistrict has the higest income inequality while the lowest inequality is the Purwatoro Subdistrict. The Composite of LQ (SLQ dan DLQ) shows that the Agricultural Sector; Electricity, Gas and Water; Trade and Communication became base sector.

Suggestions from this study cover the government of Wonogiri District is expected to improve infrastructures such as road, bridge, irrigation canal, and communication network. In addition, the Government of Wonogiri District should develop the potency of economy in each of subdistricts.
\end{abstract}

Keywords: Income Inequality, Base Sector, Non Base Sector JEL Classification: R11, R12 


\section{PENDAHULUAN}

Pembangunan ekonomi merupakan suatu proses untuk mendorong peningkatan pendapatan riil perkapita penduduk di suatu negara dalam jangka panjang. Proses tersebut juga diarahkan pada perbaikan sistem kelembagaan. Peningkatan pendapatan dan kelembagaan akan berakhir pada capaian kesejahteraan masyarakat. Pembangunan ekonomi yang merata dapat mengurangi masalah-masalah ekonomi, seperti: kemiskinan, pengangguran dan ketimpangan di suatu daerah (Arsyad, 2010).

Todaro dan Smith (2003) menjelaskan bahwa keberhasilan pembangunan ekonomi suatu negara ditunjukkan oleh tiga nilai pokok, yaitu: (1) perkembangan kemampuan masyarakat untuk memenuhi kebutuhan pokok; (2) peningkatan rasa harga diri masyarakat; dan (3) peningkatan kemampuan masyarakat untuk memilih. Ketiga nilai pokok tersebut akan mendorong perkembangan pembangunan ekonomi yang cenderung positif dan merata.

Lebih lanjut Kuncoro (2012) mengidentifikasi masalah pokok dalam pembangunan ekonomi daerah yaitu menekankan kebijakan pembangunan berdasarkan potensi daerah (endogenous development). Potensi daerah tersebut dapat dilihat dari beberapa indikator, yaitu: potensi SDM, kelembagan, dan sumberdaya fisik.

Pemerintah pusat dalam proses memajukan pembangunan daerah membentuk kebijakan Otonomi Daerah memberikan kewenangan yang seluas-luasnya kepada daerah, khususnya daerah kabupaten/kota untuk menyelenggarakan pembangunan dan mengurus rumah tangganya sendiri. De- ngan adanya kebijkan ini diharapkan pemerintah daerah dapat mengelola potensi-potensi yang terdapat pada daerah tersebut. Dalam otonomi daerah ada dua kondisi yang mempengaruhi perencanaan pembangunan daerah, yaitu: (1) tekanan yang berasal dari lingkungan dalam negeri maupun luar negeri yang mempengaruhi kebutuhan daerah dalam proses pembangunan perekonomiannya; (2) kenyataan bahwa perekonomian daerah dalam suatu negara dipengaruhi oleh setiap sektor secara berbeda-beda, misalnya: beberapa daerah mengalami pertumbuhan pada sektor industrinya sedangkan daerah lain mengalami penurunan pada sektor yang sama (Kuncuro, 2004).

Salah satu indikator keberhasilan perekonomian suatu daerah dapat dilihat pada laju pertumbuhan ekonominya. Pertumbuhan ekonomi yang tinggi dan berkelanjutan merupakan kondisi utama bagi keberlangsungan pembangunan ekonomi. Pertumbuhan ekonomi daerah di-peroleh dari nilai Produk Domestik Regional Bruto (PDRB). Suatu daerah yang meningkatkan nilai PDRB dari tahun ke tahun dapat dikatakan bahwa daerah tersebut diharapkan mengarah pada pertumbu-han ekonomi yang positif (Lihat Tabel 1).

Tabel 1. Rata-rata Pertumbuhan Ekonomi Kabupaten Wonogiri

Tahun 2010-2014 (\%)

\begin{tabular}{|c|c|c|}
\hline Tahum & $\begin{array}{l}\text { Kabupatent } \\
\text { Wommgiit }\end{array}$ & $\begin{array}{l}\text { Ratli 1:ta } \\
\text { Keccormalau }\end{array}$ \\
\hline 2010 & 3,14 & $2,9,3$ \\
\hline 2011 & 4,72 & 4,47 \\
\hline 2012 & 6,12 & 5.68 \\
\hline 2013 & 1,34 & 4.13 \\
\hline 2014 & 5,39 & 5,01 \\
\hline
\end{tabular}

Sumber: BPS Kabupaten Wonogiri , 2014 
Perbedaan tingkat pertumbuhan ekonomi baik di tingkat kabupaten maupun kecamatan di Kabupaten Wonogiri dapat dianalisis tentang ketimpangan pendapatan dan sektor basis ekonominya. Ketimpangan pendapatan dalam suatu daerah atau wilayah akan menimbulkan permasalahan di daerah tersebut. Ketimpangan yang tinggi akan berdampak buruk bagi stabilitas ekonomi daerah. Sehingga ketimpangan yang terjadi harus diatasi agar tidak semakin meningkat dari tahun ke tahun. Akan tetapi, usaha untuk menciptakan pemerataan dan mengurangi ketimpangan pendapatan sangatlah tidak mudah, terutama yang disebabkan oleh trade off antara ketimpangan pendapatan dan pertumbuhan ekonomi (Todaro, 2003).

Tabel 2. PDRB ADHK menurut Kecamatan di Kabupaten Wonogiri Tahun 2010-2014 (juta rupiah)

\begin{tabular}{|c|c|c|}
\hline Tatum & $\begin{array}{c}\text { Kabupaten } \\
\text { Wonogiui }\end{array}$ & $\begin{array}{c}\text { Rata-rara } \\
\text { Kecamatam }\end{array}$ \\
\hline 2010 & 2.992 .794 .29 & $415.212,47$ \\
\hline 2011 & 2.992 .791 .29 & $129.065,18$ \\
2012 & $3.325 .850,97$ & $110.912,13$ \\
2013 & $3.470 .018,11$ & $456.512,50$ \\
2014 & $3.657 .111,80$ & $469.510,04$ \\
\hline
\end{tabular}

Sumber: BPS Kabupaten Wonogiri (2014)

Tabel 2 menunjukkan bahwa rata-rata PDRB kecamatan di Kabupaten Wonogiri mempunyai perbedaan yang cukup besar dibandingkan PDRB Kabupaten Wonogiri. PDRB Kabupaten Wonogiri mengalami peningkatan tiap tahun, begitu pula yang terjadi di tiap kecamatan di Kabupaten Wonogiri. Hal tersebut merupakan indikator adanya ketidakmerataan sehingga akan menyebabkan terjadinya ketimpangan atau disparitas pendapatan antar kecamatan di Kabupaten Wonogiri.
Ketimpangan pendapatan merupakan masalah serius yang terjadi di setiap daerah. Masalah ketimpangan tersebut harus segera diatasi agar tidak semakin membesar. Berbagai upaya dalam mengatasi masalah ketimpangan pendapatan salah satunya dapat dilakukan dengan cara menganalisis adanya sektor-sektor basis di daerah tersebut. Adanya sektor basis yang memiliki keunggulan kompetitif maupun komparatif dapat dikembangkan sebagai salah satu cara untuk mengatasi masalah ketimpangan yang terjadi. Kemampuan daerah dalam menganalisis sektor basis sangat penting karena kontribusi sektor basis terhadap perkembangan perekonomian suatau daerah sangat besar.

Beberapa rujukan studi empiris tentang ketimpangan ekonomi antar daerah, dapat dilihat pada Mahardiki dan Priyo (2013) dan Kuncoro (2013). Ditambah dengan artikel-artikel jurnal yang menggunakan pendekatan IW, ET, dan SLQ-DLQ (baik artikel nasional maupun asing).

Berdasarkan dari latar belakang dan rujukan penelitian sebelumnya, penelitian ini akan menganalisis seberapa besar ketimpangan pendapatan dan sektor basis antar kecamatan di Kabupaten Wonogiri. Untuk itu judul penelitian ini adalah Analisis Ketimpangan Pendapatan dan Identifikasi Sektor Basis Antar Kecamatan Di Kabupaten Wonogiri Tahun 20102014.

\section{TINJAUAN PUSTAKA DAN HIPOTESIS}

Menurut Arsyad (2010) pembangunan ekonomi pada umumnya diartikan sebagai suatu proses yang menyebabkan kenaikan pendapatan seca- 
ra riil perkapita penduduk suatu negara dalam jangka panjang yang disertai oleh perbaikan sistem kelembagaan.

Menurut Kuznets dalam Todaro (2003) mendefinisikan pertumbuhan ekonomi sebagai suatu proses kenaikan kapasitas dalam jangka panjang dari negara yang bersangkutan untuk menyediakan berbagai barang ekonomi kepada penduduknya. Kenaikan kapasitas terebut ditentukan oleh adanya kemajuan dan penyesuaian-penyesuaian teknologi, institusional dan ideologis terhadap tuntutan keadaan yang ada.

Menurut Arsyad (2010) beberapa teori yang digunakan dalam pembangunan ekonomi daerah sebagai berikut :

1. Teori Ekonomi Neo Klasik Teori ini memberikan dua konsep penting dalam pembangunan ekonomi daerah, yaitu keseimbangan (equilibrum) dan mobilitas faktor produksi. Artinya, sistem perekonomian akan mencapai keseimbangan alamiahnya jika modal dapat mengalir tanpa restriksi (pembatasan).

2. Teori basis Ekonomi

Teori basis ekonomi ini menyatakan bahwa faktor penentu utama pertumbuhan ekonomi suatu daerah berhubungan langsung dengan permintaan akan barang dan jasa dari luar daerah. Pertumbuhan industri-industri yang menggunakan sumberdaya lokal, termasuk tenaga kerja dan bahan baku untuk kemudian diekspor, sehingga akan menghasilkan kekayaan daerah dan penciptaan peluang kerja (job creation) baru.

3. Teori Lokasi
Teori ini mengatakan bahwa lokasi merupakan salah satu faktor yang dapat mempengaruhi pertumbuhan ekonomi suatu dae-rah karena berkaitan dengan pengembangan kawasan industri.

4. Teori Tempat Sentral

Teori ini memandang bahwa ada hirerki tempat. Jadi, setiap tempat sentral didukung oleh sejumlah tempat yang lebih kecil yang menyediakan sumberdaya (industri dan bahan baku). Tempat sentral tersebut merupakan suatu pemukiman yang menyediakan jasa-jasa bagi penduduk daerah yang bersangkutan.

5. Teori Kausasi Kumulatif Dalam teori ini, Myrdal menjelaskan bahwa dalam proses pembangunan terdapat faktor-faktor yang akan memperburuk perbedaan tingkat pembangunan diberbagai daerah. Keadaan tersebut muncul sebagai akibat dari berlangsungnya proses kausasi kumulatif.

6. Teori Model Daya Tarik

Teori daya tarik industri adalah model pembangunan ekonomi yang paling banyak digunakan oleh masyarakat. Teori ekonomi yang mendasarinya adalah bahwa suatu masyarakat dapat mem-perbaiki posisi pasarnya terhadap para industrialis melalui pemberian subsidi dan insentif.

Menurut Tarigan (2004) menjelaskan bahwa analisis basis dan non basis pada umumnya didasarkan pada nilai tambah ataupun lapangan kerja. Misalnya, penggabungan lapangan kerja basis dan lapangan kerja non basis merupakan total lapangan kerja yang tersedia untuk wilayah tersebut. Te- 
ori basis ekonomi dibagi menjadi 2 sektor dalam perekonomian regional, yaitu: (Tarigan, 2004).

a. Sektor Basis adalah sektor-sektor yang mengekspor barang dan jasa ke tempat diluar perbatasan perekonomian masyarakat atau memasarkan barang dan jasa kepada orang yang datang dari luar batas perekonomian masyarakat bersangkutan.

b. Sektor bukan basis adalah sektor-sektor yang menyediakan barang dan jasa yang dibutuhkan oleh orang-orang dalam batas perekonomian masyarakat yang bersangkutan.

Menurut Dumairy (1996), ketimpangan regional dalam pembangunan dapat disebabkan dengan melihat suatu perbedaan mencolok dalam aspek-aspek seperti: penyerapan tenaga kerja, alokasi dan perbankan, investasi dan pertumbuhan. Indikator dalam menganalisis ketimpangan pembangunan daerah : 1) Distribusi Produk Domestik Regional Bruto (PDRB), 2) Variasi Konsumsi Rumah Tangga Per Kapita, 3) Human Development Index (HDI), 4) Kontribusi Sektoral terhadap PDRB, 5) Struktur Fiskal, 6) Tingkat Kemiskinan.

\section{METODE PENELITIAN}

Data yang digunakan dalam penelitian ini adalah data sekunder yang diperoleh dari Badan Pusat Statistik Kabupaten Wonogiri Tahun 20102014. Data yang diperlukan antara lain Produk Domestik Regional Bruto baik kecamatan dan Kabupaten Wonogiri, PDRB perkapita kecamatan dan Kabupaten Wonogiri, Jumlah penduduk kecamatan dan Kabupaten Wonogiri. A- dapun analisis data yang digunakan dalam penelitian ini sebagai berikut :

1. Analisis Ketimpangan Pendapatan

a. Indeks Williamson

Indeks Williamson meneliti hubungan antara disparitas regional dengan tingkat pembangunan ekonomi, dengan menggunakan data ekonomi negara yang sudah maju dan yang sedang berkembang. Rumus Indeks Williamson adalah sebagai berikut menurut (Sjafrizal dalam Kuncoro, 133) :

$$
\mathrm{N} w-\frac{\sqrt{\sum(Y i-Y)^{2} f i / n}}{Y}
$$

Keterangan :

$\mathrm{Yi}=\mathrm{PDRB}$ perkapita kecamatan

$\mathrm{Y}=\mathrm{PDRB}$ perkapita rata-rata seluruh kecamatan

$\mathrm{Fi}=$ Jumlah penduduk kecamatan

$\mathrm{n}$ =Jumlah penduduk seluruh kecamatan

Nilai Indeks Williamson apabila nilainya mendekati 0 berarti distribusi PDRB di suatu wilayah sangat merata dan sebaliknya bila nilainya mendekati 1 berarti tingkat ketimpangan atau disparitas di wilayah ter-sebut sangat tinggi (Tambunan, 2001).

b. Indeks Entropi Theil

Konsep Entropi merupakan teori informasi dalam mengukur kesenjangan ekonomi dan konsentrasi industri pada suatu wilayah. Indeks Entropi Theil memberikan pandangan yang tajam mengenai pendapatan regional per kapita dan kesenjangan pendapatan, kesenjangan internasional, serta distribusi produk domestik bruto dunia $(\mathrm{Ku}-$ ncoro, 133). Indeks Entropy Theil dapat dihitung dengan perhitungan sebagai berikut (Kuncoro, 2002):

$$
\mathbf{I}(\mathbf{y})=\sum \frac{\gamma i}{\mathbf{Y}} \operatorname{siog}\left[\left(\frac{\mathbf{y}}{\mathbf{Y}}\right) /\left(\frac{\mathbf{x}}{\mathbf{x}}\right)\right]
$$

Keterangan :

$\mathrm{I}(\mathrm{y})=$ Indeks Entropi Theil 
$\mathrm{Yj}=$ PDRB perkapita masing-masing kecamatan

$\mathrm{Y}=$ Rata-rata $\mathrm{PDRB}$ perkapita kabupaten

$\mathrm{Xj} \quad=$ Jumlah penduduk kecamatan

$\mathrm{X}=$ Jumlah penduduk kabupaten

Indeks Entropy Theil yang se-

makin besar menunjukkan bahwa ketimpangan yang terdapat pada suatu daerah/wilayah semakin besar atau ketimpangan di daerah tersebut tidak merata. Demikian juga, apabila indeks Entropy Theil semakin kecil menunjukkan bahwa ketimpangan yang terdapat di suatu daerah/wilayah tersebut semakin kecil/rendah atau dapat dikatakan ketimpangan pada daerah tersebut semakin merata (Kuncoro, 2004).

\section{Analisis Sektor Basis \\ a. Static Location Quotient}

SLQ adalah suatu perbandingan tentang besarnya peran suatu sektor atau industri di suatu kecamatan terhadap besarnya peran sektor atau industri di kabupaten. SLQ dirumuskan sebagai berikut (Widodo, 2006) :

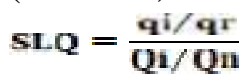

Keterangan :

qi = Pendapatan (PDRB) sektor i pada wilayah kecamatan

qr = Pendapatan (PDRB) total pada wilayah kecamatan

Qi = Pendapatan (PDRB) sektor i pada wilayah kabupaten

Qn = Pendapatan (PDRB) total pada wilayah kabupaten

Berdasarkan rumus diatas dapat dijelaskan bahwa jika koefisien nilai SLQ>1, maka sektor tersebut cenderung akan mengekspor output produksinya ke wilayah lain, atau mungkin mengekspor ke luar negeri. Sementara itu, jika koefisien nilai SLQ $<1$ berarti bahwa sektor di daerah tersebut cenderung mengimpor dari wilayah lain atau dari luar negeri.

\section{b. Dynamic Location Quotient}

DLQ adalah metode yang digunakan untuk mengetahui perubahan posisi sektor perekonomian di masa yang akan datang.

DLQ dirumuskan se-bagai berikut (Widodo, 2006):

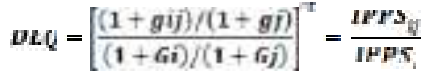

Keterangan :

gij =Laju pertumbuhan sektor i kecamatan

gj =Rata-rata laju pertumbuhan PDRB seluruh sektor kecamatan

$\mathrm{Gi} \quad=$ Laju pertumbuhan sektor i kabupaten

$\mathrm{Gj} \quad=$ Rata-rata laju pertumbuhan PDRB seluruh sektor kabupaten

$\mathrm{t} \quad=$ Selisih tahun penelitian

IPPSij =Indeks potensi pengembangan sektor i di kecamatan

IPPSi =Indeks potensi pengembangan sektor i di kabupaten

Apabila nilai DLQ $>1$, maka potensi perkembangan sektor i di suatu kecamatan lebih cepat dibandingkan dengan sektor yang sama di kabupaten. Apabila nilai DLQ $<1$, maka potensi perkembangan sektor di kecamatan lebih rendah dibandingkan dengan sektor di kabupaten secara keseluruhan.

\section{ANALISIS DATA DAN PEMBAHASAN}

1. Analisis Ketimpangan Pendapatan

a. Indeks Williamson

Tingkat ketimpangan di Kabupaten Wonogiri dapat dilihat dari pendapatan di 25 kecamatan di Kabupaten Wonogiri. Tingkat ketimpangan di masing-masing kecamatan akan mem- 
bentuk ketimpangan di tingkat Kabupaten Wonogiri. Secara rinci tingkat ketimpangan yang dihitung dengan menggunakan Indeks Williamson tiap kecamatan di Kabupaten Wonogiri pada tahun 2010-2014 dapat dilihat dalam tabel berikut :

Tabel 3. Indeks Williamson Menurut Kecamatan di Kabupaten Wonogiri Tahun 2010-2014

\begin{tabular}{|c|c|c|c|c|c|c|}
\hline \multirow{2}{*}{ No } & \multirow{2}{*}{ Kecamatan } & \multicolumn{5}{|c|}{ Tahum } \\
\hline & & 2010 & 2011 & 2012 & 2013 & 2014 \\
\hline 1 & Pracim antoro & 0.017 & 0.021 & 0.017 & 0.017 & 0.018 \\
\hline 3 & Parampupilas & 0,010 & 1) 017 & 0,033 & 6.6i3! & 0.637 \\
\hline 3 & Zirifontes & $0(x)$ & 1) (xin) & $0(x: x)$ & O) & $0(x+1)$ \\
\hline 4 & Uiriwoye & 0,029 & 0,003 & 0,000 & $0,00:$ & 0.006 \\
\hline 5 & Datuwamo & 0.026 & 0.027 & 0,026 & 0.025 & 0,021 \\
\hline 6 & Earangtengah & 0.084 & 0.053 & 0.059 & 0.001 & 0.053 \\
\hline 7 & Titomovo & 0,028 & $0,0=0$ & 0,078 & 0.078 & $0,0>7$ \\
\hline 8 & Ngutescinati & 0.00 .88 & 0.008 & 0,0009 & 0,007 & 0,003 \\
\hline 2 & Beturzmo & 0,050 & 0.007 & 0.027 & 0.003 & 0.002 \\
\hline 10 & Eromeko & 0,002 & 0.051 & 0,021 & 0,003 & 0,001 \\
\hline 11 & Wuryantoro & 0.075 & 0.075 & 0,034 & 0.035 & 0.032 \\
\hline 17 & M.uvariu & $0,0=3$ & $0,0=1$ & 0,031 & 0.010 & 0,031 \\
\hline 13 & Xi-loyiti & $0,0 / 1$ & 1) $0+9$ & $0,0) 38$ & 0 (13) & 0.038 \\
\hline 14 & Worogiri & 0.117 & 0,107 & 0.113 & 0.122 & 0,126 \\
\hline 15 & Ngadircjo & 0.050 & 0.076 & 0.074 & 0.677 & 0.083 \\
\hline 16 & Sidoharjo & 0.000 & 0.006 & 0.005 & 0.003 & 0.003 \\
\hline 17 & Jatiralin & $0,0) 1$ & 1) $(8)=7$ & $0,0,3$ & $0,0,1$ & $0,0,2$ \\
\hline $1 x$ & Kismantutsa & $00+1$ & 12013 & 0.076 & $0 \mathrm{CH}$ & $00-96$ \\
\hline 19 & purwaribus & $0,0 \% 3$ & $0.0: 3$ & $0,0,3$ & 0,018 & 0,019 \\
\hline 20 & Dulukerto & 0.017 & 0.014 & 0.015 & 0.015 & 0.016 \\
\hline 21 & Puhpelem & 0,023 & 0.015 & 0.017 & 0.017 & 0.017 \\
\hline 22 & Slogohimo & 0,070 & 0.059 & 0.070 & 0.070 & 0.072 \\
\hline 23 & Iatistotio & 0,044 & 0,043 & 0,041 & 0.038 & 0.035 \\
\hline 24 & satpurno & 0.001 & 0.044 & 0.044 & $0,0-12$ & 0.045 \\
\hline 25 & Girimarto & 0,045 & 0.033 & 0,032 & 0,032 & 0.033 \\
\hline & IW & $0,2,43$ & $0,2,15$ & 0.215 & 0,221 & 0,227 \\
\hline
\end{tabular}

Sumber : BPS Kabupaten Wonogiri Tahun 2010-2014 (diolah)

Berdasarkan Tabel 3 menunjukkan bahwa ketimpangan pendapatan di Kabupaten Wonogiri mengalami fluktuatif. Tingkat ketimpangan pendapatan paling tinggi terjadi di tahun 2010 sebesar 0,243 turun men-jadi 0,215 pada tahun berikutnya (2011). Tingkat ketimpangan pada tahun 2012 tidak mengalami perubahan seperti tahun sebelumnya yaitu sebesar 0,215. Tetapi dalam dua tahun terakhir tingkat ketimpangan terus mengalami peningkatan hingga tahun 2014 nilai sebesar 0,222. Hal ini menunjukkan adanya ketimpangan pendapatan di wilayah Kabupaten Wonogiri.

Tingkat ketimpangan pendapatan paling besar antar kecamatan di Kabupaten Wonogiri terdapat di Kecamatan Wonogiri yang merupakan Ibukota Kabupaten. Perkembangan ketimpangan pendapatan yang terjadi di Kecamatan Wonogiri tahun 2010 sebesar 0,117 turun menjadi 0,107 di tahun 2011. Ketimpangan pendapatan mengalami kenaikan di tahun 2012 sebesar 0,113 dan terus mengalami kenaikan hingga tahun 2014 sebesar 0,126.

Sementara itu, kecamatan dengan ketimpangan pendapatan paling kecil berada di Kecamatan Eromoko. Perkembangan ketimpangan pendapatan yang terjadi di Kecamatan Eromoko dari tahun 2010 sebesar 0,002, mengalami penurunan menjadi 0,001 pada tahun 2011 dan 2012. Ketimpangan pendapatan pada tahun 2013 kembali mengalami kenaikan sebesar 0,003 dan mengalami penurunan pada tahun berikutnya menjadi 0,001 . Secara keseluruhan ke-timpangan yang terjadi di Kecamatan Eromoko cenderung berfluktuatif.

b. Indeks Entropi Theil

Selain menggunakan Indeks Williamson untuk mengukur tingkat ketimpangan yang terjadi di suatu daerah atau wilayah, dapat pula menggunakan analisis dengan Indeks Entropi Theil. Indeks ini dapat di-gunakan untuk menganalisis kecenderungan konsentrasi geografis selama periode waktu tertentu dan memberikan gam- 
baran yang lebih rinci mengenai ketimpangan spasial. Selain itu, Indeks Entropi Theil tidak mem-punyai batas bawah ataupun batas atas. Nilai Indeks Entropi Theil semakin besar menandakan bahwa ketimpangan yang terjadi di daerah tersebut semakin besar. Apabila nilai Indeks Entropi Theil semakin kecil menunjukkan bahwa ketimpangan yang terjadi di daerah tersebut semakin kecil pula.

Secara rinci ketimpangan yang dihitung dengan Indeks Entropi Theil tiap kecamatan di Kabupaten Wonogiri pada tahun 2010-2014 dapat dilihat dalam tabel berikut :

Tabel 4. Indeks Entropi Theil Menurut Kecamatan di Kabupaten Wonogiri Tahun 2010-2014

\begin{tabular}{|c|c|c|c|c|c|c|}
\hline \multirow{2}{*}{ No } & \multirow{2}{*}{ Kecamalan } & \multicolumn{5}{|c|}{ Llasil Indeks Lntropi I beil } \\
\hline & & 2010 & 2011 & 2012 & 2013 & 2014 \\
\hline 1 & Pracimantors & 1,10 & $1.6 ?$ & $1.6 \%$ & 1,09 & 1,08 \\
\hline 2 & Priangoupito & 2,44 & 2,38 & 2,31 & 2,37 & 2,33 \\
\hline 3 & Giritentyo & 1,38 & 1.62 & 1.68 & 1.70 & 1,59 \\
\hline 4 & Gitiveye & 1,33 & 1,48 & 1,49 & 1,48 & 1,47 \\
\hline 5 & Batuwamo & 2,19 & 2,20 & 2.17 & 2,16 & 2,08 \\
\hline 6 & Faranglcugah & 2,98 & 2.50 & 2.44 & 2,46 & 2,35 \\
\hline 7 & Tirtomcye & 1,08 & 1.05 & 1.07 & 1,08 & 1,08 \\
\hline y & Nguntorouadi & $1, / 2$ & 1.12 & $1 . / 5$ & 1,11 & 1,52 \\
\hline 9 & Baturctac & 1,28 & 1.25 & 1.27 & 1,30 & 1,31 \\
\hline 10 & Eromolio & 1,39 & $1.3 !$ & $1.3 !$ & 1,38 & 1,51 \\
\hline 11 & Wuryanicie & 2,00 & $1, \infty 9$ & $1, \infty 9$ & 1,99 & 1,95 \\
\hline 12 & Marparan & 1,78 & 1.78 & 1.78 & 1,84 & 1,78 \\
\hline 13 & Stelegiri & 0.78 & 1.01 & 1.06 & 1.08 & 1.06 \\
\hline 14 & Wunugizi & 1,79 & 1,67 & 1.70 & 1,76 & 1,78 \\
\hline 15 & Ngacíroju & 1.81 & 1.80 & 1.79 & 1.81 & 1.85 \\
\hline 16 & Sidoturjo & 1.38 & 1,32 & 1,32 & 1.34 & 1.34 \\
\hline 17 & Initus: & 097 & 091 & 095 & 0.95 & 091 \\
\hline 18 & Fidmantoro & 1.08 & 1.01 & 1.09 & 1.00 & 0.99 \\
\hline 19 & Poxwartar & 0.58 & 390 & 0.90 & 0.93 & 073 \\
\hline 20 & Buluherie: & 1.32 & 1.36 & 1.31 & 1.35 & 1.33 \\
\hline 21 & Phlyelmu & 2311 & 191 & 191 & 193 & 144 \\
\hline 22 & Slogshimo & 0.78 & 0.79 & 0.78 & 0.79 & 0.77 \\
\hline 23 & $\mathrm{~J}_{\mathrm{x}} \mathrm{I}_{\mathrm{arche}}$ & 0,93 & 0.24 & 0.95 & 0,97 & 0,99 \\
\hline 21 & Jajipuruo & 0.87 & 1.03 & 1.03 & 1.03 & 1.02 \\
\hline 25 & Givinarto & 0.98 & 1.10 & 1.11 & 1.11 & 1.10 \\
\hline \multicolumn{2}{|c|}{ Kab Wonogiri } & 1,462 & 1,460 & 1,452 & $1,4 \leq 0$ & 1,465 \\
\hline
\end{tabular}

Sumber : BPS Kabupaten Wonogiri Tahun 2010-2014 (diolah)

Hasil dari analisis Indeks Entropi Theil menunjukkan bahwa ketimpangan pendapatan yang terjadi di Kabupaten Wonogiri berfluktuatif. Perkembangan Indeks Entropi Theil dari tahun ke tahun besarnya fluktuatif yang mana pada tahun 2010 sebesar 1,462 turun menjadi 1,460 (2011). Pada tahun 2012 angka ketimpangan sebesar 1,452 turun menjadi 1,450 (2013) kemudian naik menjadi 1,465 (2014).

Tabel 4 menunjukkan bahwa kecamatan dengan ketimpangan pendapatan paling besar terdapat di Kecamatan Karangtengah. Perkembangan Indeks Entropi Theil dari tahun 20102014 di Kecamatan Karangtengah mengalami penurunan. Hal ini dapat dikatakan ketimpangan yang terjadi semakin merata. Pada tahun 2010 besarnya Indeks Entropi Theil di Kecamatan Karangtengah sebesar 2,98 turun menjadi 2,50 (2011). Angka ketimpangan turun pada tahun 2012 sebesar 2,44 namun pada tahun 2013 mengalami kenaikan sebesar 2,46. Pada tahun 2014 angka ketimpangan kembali mengalami penurunan menjadi 2,35 . Secara keseluruhan selama tahun 20-102014 ketimpangan yang terjadi di Kecamatan Karangtengah mengalami penurunan.

Kecamatan dengan Indeks Entropi Theil paling kecil terdapat di $\mathrm{Ke}$ camatan Slogohimo. Hal ini menunjukkan bahwa ketimpangan di Kecamatan Slogohimo paling merata dibandingkan dengan kecamatan lain di Wilayah Kabupaten Wonogiri. Perkembangan ketimpangan pendapatan yang terjadi di Kecamatan Slogohimo dari tahun 2010-2014 berfluktuatif. Ketim- 
pangan yang terjadi pada tahun 2010 sebesar 0,78 mengalami kenaikan menjadi 0,79 tahun 2011. Pada tahun 2012 sempat mengalami penurunan sebesar 0,78 namun kembali naik sebesar 0,79 pada tahun 2013. Pada tahun 2014 angka ketimpangan di Kecamatan Slogohimo mengalami penurunan menjadi 0,77. Secara keseluruhan ketimpangan yang terjadi di Kecamatan Slogihimo selama tahun 20102014 mengalami penurunan.

2. Analisis Sektor Basis

a. Static Location Quotient

Static location Quotient (SLQ) merupakan salah satu analisis yang digunakan dalam menentukan sektor unggulan yang terdapat di suatu daerah/wilayah. Perhitungan analisis SLQ menggunakan PDRB Atas Dasar Harga Konstan (ADHK) dengan cara membandingkan besarnya nilai sektor ekonomi di tingkat kecamatan dengan nilai sektor ekonomi yang sama di tingkat Kabupaten Wonogiri sehingga dapat diketahui sektor basis dan non basis di tiap kecamatan. Hasil dari perhitungan SLQ tiap kecamatan di Kabupaten Wonogiri pada tahun 20102014 sebagai berikut :

\footnotetext{
Tabel 5. Hasil Analisis SLQ Menurut Kecamatan di Kabupaten Wonogiri Menggunakan PDRB ADHK Tahun 20102014
}

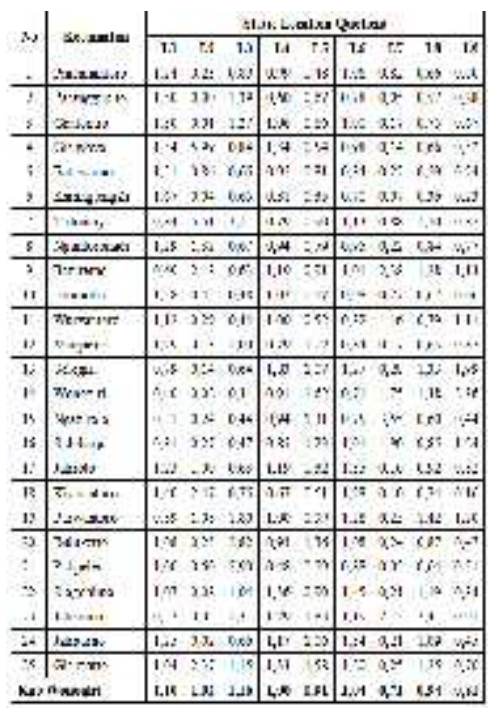

Sumber : BPS Kabupaten Wonogiri Tahun 2010-2014 (diolah)

Hasil dari analisis Static Location Quotient (SLQ) adalah apabila nilai SLQ lebih besar dari 1 (SLQ>1) maka sektor tersebut me-rupakan sektor basis. Apabila nilai SLQ lebih kecil dari 1 (SLQ<1) maka sektor tersebut bukan menjadi sektor basis di wilayah tersebut.

Sektor pertanian merupakan sektor basis yang tersebar di 17 kecamatan. Sektor tersebut menjadi sektor basis terbesar yang terdapat di Kecamatan Karangtengah dengan nilai SLQ sebesar 1,67.

Sektor pertambangan dan penggalian merupakan sektor basis yang tersebar di 8 kecamatan. Sektor tersebut menjadi sektor basis terbesar yang terdapat di Kecamatan Giriwoyo dengan nilai SLQ sebesar 5,99.

Sektor industri pengolahan merupakan sektor basis yang tersebar di 10 kecamatan sektor industri pengolahan menjadi sektor basis terbesar yang terdapat di Kecamatan Puhpelem dengan nilai SLQ sebesar 5,90.

Sektor listrik, gas, dan air bersih merupakan sektor basis yang 
tersebar di 17 kecamatan. Sektor tersebut menjadi sektor basis terbesar yang terdapat di Kecamatan Selogiri dengan nilai SLQ sebesar 1,83.

Sektor bangunan merupakan sektor basis yang tersebar di 9 kecamatan. Sektor tersebut menjadi sektor basis terbesar yang terdapat di Kecamatan Jatisrono dengan nilai SLQ sebesar 1,83 .

Sektor perdagangan, hotel dan restoran merupakan sektor basis yang tersebar di 14 kecamatan. Sektor perdagangan, hotel dan restoran menjadi sektor basis terbesar yang terdapat di Kecamatan Slogohimo dengan nilai SLQ sebesar 1,45.

Sektor pengangkutan dan komunikasi merupakan sektor basis yang tersebar di 7 kecamatan. Sektor pengangkutan dan komunikasi menjadi sektor basis terbesar yang terdapat di Kecamatan Ngadirojo dengan nilai SLQ sebesar 3,55.

Sektor keuangan, sewa, dan jasa perusahaan merupakan sektor basis yang tersebar di 9 kecamatan. Sektor keuangan menjadi sektor basis terbesar yang terdapat di Kecamatan Jatisrono dengan nilai SLQ sebesar 2,41.

Sektor jasa-jasa merupakan sektor basis yang tersebar di 6 kecamatan. Sektor tersebut menjadi sektor basis terbesar yang terdapat di Kecamatan Wonogiri dengan nilai SLQ sebesar 2,86 .

\section{b. Dynamic Location Quo- tient}

Analisis Dynamic Location Quotient (DLQ) digunakan untuk mengetahui perubahan posisi sektor perekonomian dimasa yang akan datang. Perhitungan analisis DLQ menggunakan rata-rata pertumbuhan ekonomi tingkat kecamatan dan tingkat kabu- paten. Nilai DLQ lebih dari 1 (DLQ>1) berarti bahwa potensi perkembangan sektor-sektor perekonomian di tiap kecamatan lebih cepat dibandingkan dengan sektor yang sama di tingkat Kabupaten Wonogiri. Apabila nilai DLQ lebih dari 1 (DLQ<1) berarti bahwa potensi perkembangan sektor-sektor perekonomian di tiap kecamatan lebih lambat dibandingkan dengan sektor yang sama di tingkat Kabupaten Wonogiri.

Berdasarkan Tabel 6 untuk perhitungan DLQ pada Kabupaten Wonogiri tahun 2010-2014 dengan menggunakan PDRB Atas Dasar Harga Konstan (ADHK) 2000 dapat diketahui yang termasuk sektor basis dan sektor non basis di masa mendatang.

Hasil dari analisis DLQ menunjukkan bahwa kecamatan yang mempunyai sektor basis terbanyak dengan 9 sektor basis terdapat di 3 kecamatan, antara lain : Kecamatan Nguntoronadi, Kecamatan Sidoharjo dan Kecamatan Slogohimo. Hal ini berarti bahwa potensi perkembangan sektorsektor perekonomian di 3 kecamatan tersebut lebih cepat dibandingkan dengan sektor yang sama di tingkat Kabupaten Wonogiri.

Berikut hasil dari perhitungan DLQ masing-masing kecamatan di Kabupaten Wonogiri :

\author{
Tabel 6. Hasil Analisis DLQ Menurut \\ Kecamatan Di Kabupaten Wonogiri
}


Menggunakan PDRB ADHK Tahun 20102014

\begin{tabular}{|c|c|c|c|c|c|c|c|c|c|c|}
\hline \multirow{2}{*}{$\mathrm{V}_{\mathrm{r}}$} & \multirow{2}{*}{ kneremston } & \multicolumn{9}{|c|}{ 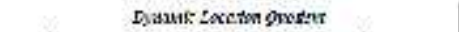 } \\
\hline & & $11 \mathrm{t}$ & 12 & I3 & $2=$ & $\mathbf{I} ;$ & 24 & $1 ?$ & LE & I2 \\
\hline 1 & Aarin-alam & 1.24 & $i ; n$ & $1: 2+$ & 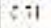 & $\because 11$ & $1 \%$ & $1 n \leq$ & Ninis & $\$$ \\
\hline$z$ & Farapolutin & 1,15 & $:, 60$ & $1,3:$ & 8,56 & $20 \mathrm{t}$ & 201 & $3 \hat{N}^{4}$ & 1128 & $2: 31$ \\
\hline$j$ & Sin $=20$ & $15, w$ & 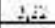 & $3,8 !$ & 1,30 & $13 j$ & 0,45 & $1 ; 8$ & 0,2 & 2,3 \\
\hline+ & viticus:n & $+1:$ & $71 \%$ & 5,12 & $T \pi$ & 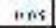 & ti.. & $4: 5$ & 10 & $\because a \mathrm{as}$ \\
\hline i & Bentwa: & 317 & 18 & 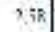 & $1 \leq n$ & $1+i$ & $1: 3$ & $\therefore: 4$ & 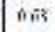 & 5.4 \\
\hline 1. & Kint.zersh & $1, j 2$ & 8,10 & 1,15 & 6,58 & 102 & 12,00 & 52: & 1,12 & $=., 11$ \\
\hline a & $7 \operatorname{mrams}$ & 8,10 & 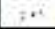 & 14 & 11 & $1 \%$ & 1.1 & $a$ & $11 \%$ & 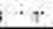 \\
\hline 5 & nuviamosi & $1 x$ & $+\cdots$ & $1: 1$ & $+1,6$ & 1.7 & 2.4 & $\mathrm{x}, 1:$ & $1: 5$ & $a x$ \\
\hline 7 & Buidits & 15,5 & 8,06 & 4,25 & 1,16 & $0 \leqslant 1$ & 165 & 1,55 & 1,21 & $\ldots$ \\
\hline is & Lnusk: & $\therefore, 2:$ & 2,21 & $L, 19$ & 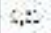 & $1: 3$ & $1: ;$ & $10:$ & Q8: & $\therefore: 2$ \\
\hline if & Aroponst & is. & $1: 5$ & $\mathrm{in}$ & $7: k$ & 321 & $\therefore ;$ & 1.12 & $10 \mathrm{~s}$ & 18 \\
\hline 15 & Karipat: & $23 !$ & $8: 2$ & 125 & $E \mathrm{~F}$ & $1 i 5$ & 8 in & 31 & 073 & 43 \\
\hline ik & Seirgest & 2,57 & $=., 26$ & 1,95 & 1,78 & 201 & $1: 28$ & 0,0 & $\therefore, 12$ & 3,9 \\
\hline 11 & \#-mogri & $1 . \%$ & $1 \ldots$ & 111 & $\therefore:-$ & $3 \%$ & $\ldots$ & $1 \%$ & $11 \mathrm{x}$ & 1 is \\
\hline 17 & Ayilmat & $\cdots$ & $\cdots z$ & $5 \leqslant$ & $\therefore 1$ & $11 \mathrm{xi}$ & $-\cdots$ & $1 \mathrm{~ns}$ & $1: 1$ & 1. $4=$ \\
\hline 12 & Hituse & $1, V Z$ & 1,52 & 15,75 & 1,12 & $+\vdots ?$ & 213 & $L, \phi 3$ & 1,42 & -43 \\
\hline ii & At: & 1,t: & 2,06 & $\mathrm{~L}, \mathrm{AS}$ & $\mathrm{I}, \mathrm{O}$ & $w . y ;$ & Iu: & 1,12 & $\approx 1$ & ز \\
\hline 14 & Kirn:Th & $1 \%$ & 336 & 1.12 & 11: & 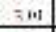 & $\cdots$ & $x:$ & not & 18 \\
\hline 13 & Pasalain: & 1,5 & $8: 71$ & 38 & $15 n$ & 109 & 119 & 117 & $1: 1$ & 43 \\
\hline 29 & B.LLCX & 1,8 & 4,21 & 1,28 & $3,2: 2$ & 1.42 & 113 & 0,25 & 0,52 & -2 \\
\hline 31 & prinselen & $t, 39$ & 3,$1 ;$ & $0,3:$ & $1,1:$ & vof & $1::$ & 120 & 4,1 & 1,33 \\
\hline$x$ & sleptrim: & $\therefore:$ & 10 & 1.4 & $1+1:$ & 114 & $1 \cdots$ & $1 ; 2$ & 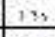 & 4 \\
\hline 3 & Sthant & $x: 7:$ & $\because n$ & 1,55 & 115 & 133 & $1: 3$ & 388 & 713 & is \\
\hline 21 & Sulume & 2,21 & 1,78 & 1,27 & $2,1:$ & 172 & 1.5 & 205 & $0,0 \mathrm{~L}$ & -39 \\
\hline ¿) & 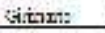 & d.I: & i.:. & d.12 & 2.14 & 1.1 & 111 & s.: & 0.01 & 1.25 \\
\hline K, & & وهز & $3 ; 3$ & |19: & 1,5s & $1,5 \mathrm{~s}$ & $2,+2$ & $\mid 1: 35$ & 2,3 & $: ., 59$ \\
\hline
\end{tabular}

Sumber : BPS Kabupaten Wonogiri Tahun 2010-2014 (diolah)

Sektor pertanian, sektor perdagangan, hotel \& restoran, dan sektor pengangkutan \& komunikasi merupakan sektor basis terbanyak yang terdapat di 24 kecamatan di Kabupaten Wonogiri. Sementara itu, Sektor keuangan, sewa \& jasa perusahaan merupakan sektor basis paling sedikit yang terdapat di 15 kecamatan di Kabupaten Wonogiri.

\section{KESIMPULAN, IMPLIKA- SI, SARAN, DAN BATA- SAN}

Berdasarkan penelitian tentang analisis ketimpangan pendapatan dan sektor basis antar kecamatan di Kabupaten Wonogiri tahun 2010-2014, maka dapat diambil kesimpulan sebagai berikut:

Berdasarkan analisis ketimpangan pendapatan dengan menggunakan Indeks Williamson dan Indeks
Entropi Theil menunjukkan bahwa: (a) Hasil dari analisis Indeks Williamson menunjukkan adanya ketimpangan pendapatan di Kabupaten Wonogiri cenderung berfluktuatif. Ketimpangan antar kecamatan paling besar di $\mathrm{Ka}-$ bupaten Wonogiri terdapat di Kecamatan Wonogiri. Sementara itu, kecamatan dengan ketimpangan pendapatan paling kecil berada di Kecamatan Eromoko. (b) Hasil dari analisis Indeks Entropi Theil menunjukkan ketimpangan pendapatan antar kecamatan di Kabupaten Wonogiri cenderung berfluktuatif. Kecamatan dengan ketimpangan pendapatan paling besar terdapat di kecamatan Karangtengah, sedangkan kecamatan dengan Indeks Ketimpangan paling kecil terdapat di kecamatan Purwantoro.

Berdasarkan hasil analisis sektor unggulan dengan menggunakan analisis Location Quotient menunjukkan bahwa: (a) Hasil analisis SLQ menunjukkan bahwa, sektor pertanian merupakan sektor basis di Kabupaten Wonogiri. Hal tersebut dikarenakan Sektor Pertanian memiliki keunggulan komparatif dan keunggulan kompetitif yang tersebar paling banyak yaitu di 17 kecamatan. Sedangkan sektor basis paling sedikit adalah sektor pengangkutan dan lomunikasi dan sektor jasa-jasa yang terdapat di 6 kecamatan. (b) Hasil analisis DLQ menunjukkan bahwa, sektor pertanian, sektor perdagangan, hotel dan restoran, sektor pengangkutan dan komunikasi merupakan sektor basis terbanyak yang tersebar di 24 kecamatan di Kabupaten Wonogiri. Sedangkan sektor keuangan, Sewa dan jasa perusahaan menjadi sektor basis paling sedikit yang terdapat di 15 kecamatan di Kabupaten Wonogiri. 
Berdasarkan kesimpulan di atas, maka dapat dikemukakan beberapa saran bagi Pemerintah Kabupaten Wonogiri sebagai berikut: (a) Dalam mengatasi masalah ketimpangan pendapatan yang terjadi antara kecamatan di Kabupaten Wonogiri, pemerintah harus melakukan pemerataan pembangunan di tiap kecamatan dengan melihat potensi-potensi yang terdapat di daerah tersebut. Selain itu, Pemerintah perlu memperbaiki infrastruktur dan fasilitas penunjang (seperti jalan, jembatan, jaringan listrik, jaringan air dan jaringan komunikasi) di masing-masing kecamatan. Dengan adanya kebijakan tersebut diharapkan ketimpangan pendapatan di wilayah Kabupaten Wonogiri lebih merata sehingga kesejahteraan masyarakat akan meningkat dan dapat mengurangi kemiskinan di wilayah Kabupaten Wonogiri. (b) Untuk meningkatkan sektor-sektor ekonomi di Kabupaten Wonogiri, pemerintah perlu mempertahankan dan mengembangkan sektor-sektor basis yang terdapat di masing-masing kecamatan karena sektor basis tersebut mempunyai andil dalam peningkatan PDRB di tingkat kabupaten. Sementara itu, pemerintah tidak boleh mengabaikan sektor non basis. Pemerintah harus membuat perencanaan kebijakan pembangunan untuk meningkatkan sektor-sektor non basis menjadi sektor basis sehingga dapat mencukupi kebutuhan masyarakatnya bahkan dapat mengekspor ke luar daerah tersebut.

\section{DAFTAR PUSTAKA}

Alhowaish, et al. (2015). Location Quotient Technique and Economy Analysis of Regions: Tabuk Province of Saudi Arabian as a Case Study. Internasional Journal of
Science and Research. Volume 4, No. 12

Arsyad, Lyncolin. (2010). Ekonomi Pembangunan. Yogyakarta: UPP STIM YKPN

Cristofakis, Manolis dan Gkouzos, Andreas. (2014). Regional Specialization and Efficiency of The Agricultural Sector in Greece: The Relationship with Regional Funding Allocation. Journal Regional and Sectoral Economic Studies. Volume 13, No. 1

Hajeri, dkk. (2015). Analisis Penentuan Sektor Unggulan Perekonomian di Kabupaten Kubu Raya. Jurnal ekonomi bisnis dan kewirausahaan. Volume 4, No. 2

Nikijuluw, Jeanee. (2014). Pertumbuhan dan Ketimpangan Pembangunan antar Daerah di Provinsi Maluku. Jurnal Ekonomi. Volume 8. No 1.

Kuncoro, Mudrajad. (2002). Analisis Spasial dan Regional : Studi Aglomerasi dan Kluster Industri Indonesia. Yogyakarta: AMP YK$\mathrm{PN}$

(2004). Otonomi dan Pembangunan Daerah: Reformasi, Perencanaan, Strategi, dan Peluang. Jakarta: Gelora Aksara Pratama

(2010). Dasar-dasar Ekonomika Pembangunan. Yogyakarta: UPP STIM YKPN

(2012). Perencanaan Daerah:Bagaimana Membangun 
Ekonomi Lokal, Kota dan Kawasan. Jakarta: Salemba Empat

Mahardiki, Doni dan Priyo, R.S. (2013). Analisis Perubahan Ketimpangan Pendapatan dan Pertumbuhan Ekonomi Antar Provinsi di Indonesia. Journal of Economics and Policy. Volume 6. No 2. Hal. 103-213

Mahyudi, Akhmad. (2004). Ekonomi Pembangunan dan Analisis Data Empiris. Bogor: Ghalia Indonesia

Nuralam, Suwandi. (2015). Economic Inequality among Districts in Keerom, Papua, Indonesia. Journal of Social and Development Sciences. Volume 6. No. 3. pp 30-34

Rahman, Abdul. (2011). Economic Growth and Regional Development Disparity in South Selawesi. Economic Journal of Emerging Market. Volume 3, No. 3. pp 275287

Suryana. (2000). Ekonomi Pembangunan: Problematika dan Pen- dekatan. Jakarta: Salemba Empat

Tarigan, Robinson. (2004). Ekonomi Regional: Teori dan Aplikasi. Jakarta: Bumi Aksara

Todaro, M.P. dan Smith, S.C. (2011). Pembangunan Ekonomi: Di Dunia Ketiga. Jakarta: Erlangga

Yuliani, Tutik. (2011). Pertumbuhan Ekonomi dan Ketimpangan Pendapatan Antar Kabupaten di Kalimantan Timur. Journal of Economics and Policy. Volume 8, No. 1. Pp 1-88

Wahyuningsih, Tri, dkk. (2014). Determination of Agriculture Sector and Subsector Potentially Leading and with Superior in Distric Hie Location Quotient metotdh Static, Dynamic Input and Output Location Quotient. Journal of Economics and Sustainable Development. Volume 5. No. 28

Widodo, Tri. (2006). Perencanaan Pembangunan: Aplikasi Komputer (Era Otonomi Daerah). Yogyakarta: UPP STIM YKPN 